ks. Paweł Rycyk CM

\title{
Zakony w funkcji krzewienia patriotyzmu
}

\section{Patriotyzm w nauczaniu Jana Pawła II}

Patriotyzm oznacza umiłowanie tego, co ojczyste: historii, tradycji, języka czy samego krajobrazu ojczystego. Jest to miłość, która obejmuje również dzieła rodaków i owoce ich geniuszu. Próbą dla tego umiłowania staje się każde zagrożenie tego dobra, jakim jest ojczyzna. Nasze dzieje uczą, że Polacy byli zawsze zdolni do wielkich ofiar dla zachowania tego dobra albo też dla jego odzyskania. Świadczą o tym tak liczne mogiły żołnierzy, którzy walczyli za Polskę na różnych frontach świata. Są one rozsiane po ziemi ojczystej oraz poza jej granicami. Wydaje mi się jednak, że jest to doświadczenie każdego kraju i każdego narodu w Europie i na świecie.

Ojczyzna jest dobrem wspólnym wszystkich obywateli i jako taka jest też wielkim obowiązkiem. Analiza dziejów dawniejszych i wspólczesnych dowodzi, że Polacy mieli odwage, nawet w stopniu heroicznym, dzięki której potrafili wywiązywać się z tego obowiązku, gdy chodziło o obronę ojczyzny jako naczelnego dobra.

\section{Fundacja Skarby Narodu}

W erze życia opartego na konsumpcjonizmie oraz materializmie młodzież nie koncentruje się na symbolice patriotyzmu, religii, ojczyzny. Młodzi ludzie swoje zainteresowanie skupiają wokół intensywnego 
życia społecznego i materialnych przyjemności, nie szukając przy tym wartości wyższych, które mogą być dla nich drogowskazami w dalszym życiu. Fundacja Skarby Narodu została powołana w czerwcu 2013 roku między innymi w celu pomocy w ukierunkowaniu i rozszerzeniu światopoglądu młodych osób oraz zaszczepienia w nich miłości do ojczyzny, własnej kultury, sztuki i tradycji narodowej. Pomysł utworzenia takiej organizacji powstał z troski o pamięć naszego narodu w młodszych pokoleniach.

Fundacja Skarby Narodu ma swoją siedzibę przy ul. Krakowskie Przedmieście 3, w bazylice Świętego Krzyża w Warszawie. Parafia ta uważana jest za narodowe sanktuarium. Działająjuż w niej Akademia Wychowania i Rodziny oraz Akademia Cnót Obywatelskich, z którymi Fundacja Skarby Narodu realizuje projekty skierowane do młodzieży. Ich celem jest umożliwianie poznawania historii, sztuki, wartości miłości i rodziny w zupełnie inny sposób niż w ten teoretyczny, z którym na co dzień ludzie młodzi spotykają się w szkole.

Poprzez swoje działania Fundacja pragnie zachęcić młodych ludzi do odkrywania i pielęgnowania polskiego dziedzictwa narodowego. W swoich projektach umożliwia młodzieży spotkania m.in. z żywymi świadkami historii, których opowieści stanowią bezcenne źródło wiedzy historycznej, z członkami różnorodnych grup rekonstrukcji historycznych oraz stowarzyszeń historycznych, a także z osobami kreującymi wizję wydarzeń historycznych na ekranie. Wśród działań Fundacji znajduje się także organizacja warsztatów, wystaw i eventów, mających na celu przybliżenie w niekonwencjonalny sposób, młodym ludziom i nie tylko, historii, kultury i tradycji polskiej.

\section{Uczymy patriotyzmu, przypominamy historię, dbamy o wartości}

Przy okazji ważnych rocznic, Mszy św. katyńskich czy odprawianych w intencji żołnierzy wyklętych w kościele trudno zobaczyć młodzież. Powołaliśmy tę fundację, bo obserwujemy, że tradycyjne wartości, jak religia czy miłość ojczyzny, są coraz mniej rozumiane przez młode pokolenie.

Chciałbym, żeby działalność fundacji to zmieniła, żeby młodzi ludzie zaczęli interesować się historią, a patriotyzm nie był tylko pustym słowem, kojarzącym się z przeszłością. 
Głównymi celami Fundacji Skarby Narodu, poza ochroną dziedzictwa narodowego, są następujące działania:

- propagowanie kultury, sztuki i tradycji związanej z Polską, a w szczególności regionem Mazowsza;

- integrowanie społeczeństwa wokół wartości kulturalnych;

- wspieranie inicjatyw kulturalnych;

- wszechstronny rozwój młodzieży w zakresie stwarzania atmosfery mobilizującej do pracy nad sobą i kształtowania osobowości w duchu poszanowania wartości patriotyzmu;

- ubogacanie wiary, zasad moralnych i etycznych w życiu osobistym i społecznym członków społeczeństwa, zapoznawanie ich z dorobkiem kultury narodowej i twórcze angażowanie w rozwój życia kulturalnego;

- propagowanie dbałości o kulturę osobistą, troski o czystość i piękno otoczenia oraz poszanowania środowiska naturalnego;

- promocja miast i twórców kultur w Polsce oraz poza jej granicami;

- popularyzacja wiedzy historycznej oraz idei patriotyzmu;

- dbałość o pamięć i wspieranie porozumienia między narodami.

Fundacja realizuje swoje cele poprzez:

- dokumentowanie oraz publikowanie na stronach internetowych informacji na temat wydarzeń historycznych odbywających się na terenie kraju, a zwłaszcza w rejonie Warszawy i Mazowsza;

- prowadzenie na portalach społecznościowych cykli edukacyjnych dla młodzieży,

- organizowanie wystaw o tematyce patriotycznej;

- organizowanie warsztatów historycznych dla młodzieży szkolnej;

- organizowanie wycieczek kulturalno-historycznych po Warszawie dla młodzieży z rodzin w trudnej sytuacji materialnej;

- pomoc w organizowaniu obchodów polskich świąt narodowych oraz innych ważnych dla kraju wydarzeń historycznych;

- aranżowanie spotkań młodzieży z żywymi świadkami historii, członkami grup rekonstrukcyjnych oraz aktorami 
i scenarzystami produkcji filmowych poświęconych historii Polski;

- wydawanie publikacji o tematyce historycznej;

- archiwizowanie prywatnych pamiątek z czasów I i II wojny światowej w celu późniejszego eksponowania ich podczas organizowanych wystaw;

- organizowanie imprez edukacyjno-kulturalnych.

Fundacja Skarby Narodu ma już na swoim koncie organizację wystaw:

\section{Ostatnia droga ks. Jerzego Popiełuszki}

\section{w fotografii Artura Radeckiego}

Wystawa składa się ze zdjęć wykonanych 2 listopada 1984 roku, kiedy to zwłoki bł. ks. Jerzego Popiełuszki zostały przewiezione z budynku Akademii Medycznej w Białymstoku do kościoła św. Stanisława Kostki na warszawskim Żoliborzu.

\section{Skarby międzywojennej Warszawy}

$\mathrm{Na}$ wystawie prezentowane były unikatowe fotografie przepięknych budynków i ulic stolicy z lat 1918-1939, książki, broszury, a także oryginalne plany miasta. Dodatkową atrakcję stanowiła z pewnością odtwarzana z przedwojennych płyt szelakowych na prawdziwym stuletnim gramofonie muzyka, która przywoływała atmosferę z tamtych lat.

\section{Marszałek Piłsudski - portret bohatera}

Oprócz licznych fotografii Marszałka z różnych okresów jego życia na wystawie prezentowane były m.in. obrazy, figurki i medale z podobizną Marszałka, książki, kartki okolicznościowe, broń i elementy umundurowania z tamtego okresu, a także oryginalne dokumenty napisane przez samego Józefa Piłsudskiego. Dodatkową atrakcję stanowiły pieśni legionowe odtwarzane z przedwojennych płyt szelakowych na prawdziwym stuletnim gramofonie. Odwiedzający mieli także okazję obejrzeć filmy dokumentalne przedstawiające najważniejsze momenty z życia politycznego Marszałka.

\section{Zaglada polskich elit. Akcja AB - Katyń}

Ekspozycja przedstawia największe akcje represyjne przeprowadzone równolegle przez Niemców i Sowietów w Polsce w pierwszych miesiącach okupacji. Na wystawie zrekonstruowane zostały przygotowania do zbrodni, jej przebieg oraz najważniejsi sprawcy. Przybliżone zostały także przykładowe sylwetki ofiar, w tym rodzin, które stały się ofiarami obu systemów. 


\section{Wystawa poświęcona historii Orderu Świętego Stanisława Bi- skupa i Męczennika}

Wystawa prezentuje dzieje Orderu od momentu jego ustanowienia przez króla Stanisława Augusta Poniatowskiego w 1765 roku aż do ostatniej inwestytury Orderu w 1830 roku. Odwiedzający ekspozycję mieli okazję zapoznać się m.in. z relacją z przebiegu pierwszej uroczystości wręczenia insygniów Orderu, treścią aktu ustanowienia Orderu oraz jego statutu sygnowanego przez Stanisława Augusta Poniatowskiego w przeddzień pierwszej inauguracji 7 maja 1765 roku. $\mathrm{Na}$ wystawie przedstawione zostały również wszystkie współczesne insygnia Orderu oraz fotografie insygniów z czasów panowania króla Stanisława Augusta wraz ze szczegółowym ich opisem. Część ekspozycji poświęcona została najznakomitszym i najbardziej znanym Kawalerom Orderu Św. Stanisława oraz ich dokonaniom.

\section{„Cum tacent, clamant” (lac., milcząc, wolają)}

Wystawa jest zapisem prac poszukiwawczych szczątków ofiar systemu komunistycznego, prowadzonych w kwaterze „Ł” na warszawskich Powązkach, gdzie pochowani zostali żołnierze podziemia niepodległościowego, pomordowani w latach 40. i 50. w więzieniach bezpieki. Prace ekshumacyjne realizowane są przez Instytut Pamięci Narodowej od lipca 2012 roku w ramach projektu Poszukiwania nieznanych miejsc pochówku ofiar terroru komunistycznego z lat 1944-1956.

\section{Niedokończone Msze Wołyńskie}

Wystawa została zorganizowana przez Fundację we współpracy z Katolickim Stowarzyszeniem „Civitas Christiana”. Jest hołdem pamięci złożonym duchownym, którzy zginęli na Kresach Wschodnich, dając świadectwo trwania i służby Kościołowi. Składa się na nią 26 plansz, na których przedstawione zostały biogramy i zdjęcia 25 osób duchownych - księży, ojców i sióstr zakonnych, zamordowanych w czasie rzezi na Wołyniu w 1943 roku. Wystawę przygotował lubelski oddział IPN-u oraz Katolicki Uniwersytet Lubelski we współpracy z konsulatem RP w Łucku.

\section{Drogi do Niepodległości}

$\mathrm{Na}$ ekspozycję składają się oryginalne elementy wyposażenia polskich żołnierzy walczących w obcych armiach o wolność naszego kraju. Wśród nich znajdują się także jedyne egzemplarze odnotowane w Polsce. 
Wystawa poświęcona działalności wojennej abpa Józefa Gawliny

Ekspozycja została przygotowana przez Instytut Polski Akcji Katolickiej w Wielkiej Brytanii, Instytut Polski i Muzeum im. gen. Sikorskiego w Londynie oraz Polską Misję Katolicką w Anglii i Walii.

\section{Więzienne lata prymasa Stefana Wyszyńskiego 1953-1956}

Wystawa składa się z 53 paneli przedstawiających archiwalne i aktualne zdjęcia z miejsc uwięzienia kardynała. Na wystawie wyeksponowano również fragmenty zapisków więziennych kardynała Wyszyńskiego. Integralną część prezentacji stanowiło kalendarium życia i działalności Prymasa Tysiąclecia.

\section{Wystawa poświęcona historii Orderu św. Stanisława}

W tym roku, 7 maja, minęła 250. rocznica ustanowienia przez króla Stanisława Augusta Poniatowskiego Orderu Św. Stanisława Biskupa Męczennika, który jest jednym z najważniejszych polskich historycznych odznaczeń zaszczytnych. Dla miłośników narodowej tradycji i kultury było to wyjątkowe święto. Z tej okazji Fundacja Skarby Narodu przygotowała niezwykłą wystawę poświęconą Orderowi i jego historii. $\mathrm{Na}$ wystawie można było m.in. poznać historię orderu, zobaczyć jego dawne i obecne insygnia, poczytać o jego najzacniejszych kawalerach, a także dowiedzieć się, jak wyglądają wspólczesne inwestytury Orderu.

\section{Dzieje świętokrzyskiej świątyni}

Z okazji kolejnej edycji Nocy Muzeów w Warszawie nasza Fundacja przygotowała specjalną wystawę poświęconą dziejom kościoła Świętego Krzyża. Były na niej prezentowane archiwalne i współczesne fotografie, a także liczne aktualne i historyczne niezwykle cenne eksponaty, wśród nich m.in. pamiątki pozostałe po świątyni zniszczonej w trakcie powstania warszawskiego.

\section{Polska Walcząca}

Wystawa przygotowana przez Instytut Pamięci Narodowej prezentuje fenomen powstania i działania Polskiego Państwa Podziemnego w latach 1939-1944. Na ekspozycji można również znaleźć informacje na temat żołnierzy wyklętych, którzy po 1944 roku kontynuowali walkę o niepodległą Polskę. Prezentowane są na niej także zdjęcia z prac poszukiwawczych prowadzonych przez IPN w kwaterze „Ł” 
i identyfikowane są szczątki bohaterów Polski Walczącej, rozstrzelanych w komunistycznych więzieniach.

35 lat transmisji przez Polskie Radio Mszy św. z kościola Świętego Krzyża w Warszawie

Wystawa obejmuje lata 1980-2015. Oprócz licznych fotografii prezentowane są na niej dokumenty archiwalne. Można na niej również zobaczyć kasety magnetofonowe oraz płyty z nagraniami wszystkich wygłoszonych dotąd kazań, a także 27 tomów Świętokrzyskich kazań radiowych. Główną atrakcją jest pomieszczenie imitujące studio radiowe $\mathrm{z}$ lat 80., z którego zapowiedziana została pierwsza transmisja Mszy św. z 21 września 1980 roku.

\section{Kościól Świętego Krzyża w obliczu wojny}

Ekspozycja poświęcona jest losom kościoła Świętego Krzyża od 1944 roku aż do jego renowacji. Na prezentowanych fotografiach możemy prześledzić, jak kolejne ciosy wroga niszczyły to sanktuarium narodowe. Na zdjęciach odnaleźć można także bohaterów tamtych dni, m.in. z kompanii „Lewar” z Grupy Bojowej „Krybar”, z Batalionów „Gustaw” i „Harnaś”, ale również żołnierzy z innych oddziałów walczących w tym rejonie. Do elementów ekspozycji należą również oryginalne, zachowane do naszych czasów w niezmienionym stanie szczątki wyposażenia kościoła Świętego Krzyża sprzed wybuchu powstania warszawskiego.

Wystawa udostępniana jest w salach wystawowych dolnego kościoła Świętego Krzyża w Warszawie.

\section{Kościoły Miasta Ruin}

Wystawa powstała z okazji 70. rocznicy powstania warszawskiego. $\mathrm{Na}$ podstawie fotografii oraz innych pamiątek, pozostałych po warszawskich kościołach, pokazany został na niej ogrom zniszczeń, jakie zostały dokonane w stolicy podczas II wojny światowej. Na ekspozycji prezentowane są 34 różne świątynie, nie tylko z rejonu Starego i Nowego Miasta, ale także ze Śródmieścia, Woli, Ochoty, Mokotowa i Pragi. Do każdego zdjęcia dołączony jest opis materialnych strat, jakie poniósł dany kościół. Wystawa została już zaprezentowana w bazylice Świętego Krzyża w Warszawie, na terenie parafii świętych Rafała i Alberta na Rudzie, w najstarszym i jednym z najcenniejszych zabytków sakralnych Ostrołęki - kościele Nawiedzenia NMP, na terenie parafii św. Stanisława Kostki w Tarnowie, w parafii Niepokalanego 
Serca NMP w Marcinkowicach, a obecnie można ją oglądać w Mediatece START-META na warszawskich Bielanach.

\section{Wycieczki historyczno-kulturalne po Warszawie}

Fundacja zorganizowała dotychczas trzy wycieczki historyczno-kulturalne po Warszawie. Jej uczestnikami byli uczniowie Szkoły Podstawowej i Publicznego Gimnazjum Nr 2 w Trzcinicy k. Jasła oraz I Liceum Ogólnokształcącego w Jaśle im. Króla Stanisława Leszczyńskiego, a także członkowie Stowarzyszenia Rozwoju Kultury Ziemi Jasielskiej. Nasi goście odwiedzili m.in. Zamek i Łazienki Królewskie, Muzeum Powstania Warszawskiego, Muzeum Ordynariatu Polowego, Muzeum Pałacu Króla Jana III w Wilanowie, Stadion Narodowy, a także Belweder oraz Sejm i Senat RP. Dodatkową atrakcją była wizyta w I Bazie Lotnictwa Transportowego. We wszystkich punktach wycieczki zwiedzającym towarzyszyli przewodnicy, a w niektórych prowadzone były także specjalnie przygotowane lekcje poświęcone kulturze, sztuce i historii polskiej.

Fundacja dysponuje ofertą wycieczek dwu- i trzydniowych po Warszawie, którą kieruje do zainteresowanych z całej Polski, oraz wycieczek jednodniowych o charakterze edukacyjnym, dedykowanych uczniom warszawskich szkół.

\section{Działalność wydawnicza Fundacji Skarby Narodu}

Ekspozycja „Kościoły Miasta Ruin” stała się inspiracją do publikacji albumu o tym samym tytule, w całości przygotowanego przez młodych ludzi z myślą o ich rówieśnikach. Książka zawiera fotografie oraz opisy zniszczeń 68 warszawskich świątyń ${ }^{1}$. Umieszczone zostały w niej także zdjęcia eksponowanych na wystawie pamiątek pozostałych po bohaterach tamtych dni.

Do każdej ze swych kolejnych wystaw Fundacja planuje wydawanie albumów edukacyjno-pamiątkowych, które będą tworzyły kilkudziesięciotomową kolekcję. Cały zbiór pozwoli zdobyć dogłębną 
wiedzę na temat życia oraz prowadzonych działań w okupowanej Polsce, a także w trakcie II wojny światowej. Z tej serii powstała już publikacja poświęcona hitlerowskim zbrodniom popełnianym w zapomnianym dzisiaj KL Warschau. Celem tej pracy jest zachowanie i kultywowanie pamięci ofiar - Polaków-warszawiaków - oraz różnych mniejszości narodowych, przywiezionych do Warszawy w celu obsługiwania tego kompleksu obozowego. Pamięć o tej tragedii narodowej ma odegrać rolę ostrzeżenia, aby nigdy więcej w historii naszej ojczyzny ani też innych krajów świata podobna ludobójcza tragedia się nie powtórzyła.

W przygotowaniu i realizacji są także wyjątkowe serie pamiątkowych pocztówek zawierające archiwalne i współczesne fotografie bazyliki Świętego Krzyża w Warszawie: „Bazylika Świętego Krzyża dziš”, „Skarby świętokrzyskiej świątyni”, „Kościół Świętego Krzyża w Powstaniu Warszawskim”, „Kościoły Miasta Ruin”.

\section{Inne osiagnięcia Fundacji Skarby Narodu}

Jednym z najważniejszych osiągnięć Fundacji było zawarcie, w wyniku kilkumiesięcznych starań prezesa Fundacji ks. Pawła Rycyka, dnia 14 grudnia 2013 roku porozumienia pomiędzy parafią Świętego Krzyża w Warszawie a Kapitułą Orderu Świętego Stanisława w sprawie przywrócenia, zgodnie z historyczną tradycją, organizacji inwestytury Orderu w bazylice Świętego Krzyża w Warszawie. Order ten został ustanowiony przez króla Stanisława Augusta Poniatowskiego w 1765 roku i był nadawany corocznie podczas majowych uroczystości ku czci św. Stanisława Biskupa w dniu 8 maja, w kościele Świętego Krzyża.

Fundacja była również współorganizatorem uroczystych inwestytur organizowanych na nowo w bazylice w 2014 i 2015 roku.

\section{Długofalowe i wielokierunkowe projekty Fundacji Skarby Narodu}

7.1. Dzień Patriotyzmu w szkołach średnich i gimnazjach

W czasach pokoju i dostatku takie wartości, jak Bóg, honor i ojczyzna odchodzą w zapomnienie. Tradycje i historia własnego narodu 
przestają być dla młodych ludzi atrakcyjne. Środki masowego przekazu zachęcają młodzież do skierowania swoich zainteresowań głównie na kulturę zachodnią. Stąd pomysł na stworzenie projektu pn. Dzień Patriotyzmu. Jest to projekt skierowany do młodych Polaków, mający na celu zachęcenie ich do zdobywania wiedzy na temat historii naszego kraju oraz zaszczepienie w nich ducha patriotyzmu i miłości do ojczyzny. Przy pomocy tej inicjatywy Fundacja Skarby Narodu pragnie również zdementować mit, iż lekcje historii muszą być nużące. Chcemy umożliwić młodzieży spotkania z żywymi świadkami historii, aby to oni, poprzez opisy własnych doświadczeń, przekazywali młodym ludziom wiedzę na temat historii Polski. Projekt dedykowany jest uczniom szkół gimnazjalnych oraz licealnych. Oferta jest całkowicie bezpłatna.

Program rozpoczyna się lekcją historii na wybrany przez szkołę temat, dostosowany do potrzeb jej wychowanków. Pełna oferta tematyczna przedstawiana jest każdej zgłaszającej się placówce. Lekcje są prowadzone przez specjalistów z dziedziny historii, zapraszanych przez Fundację. Kolejnym punktem programu jest pokaz, w zależności od tematyki spotkania, umundurowania, uzbrojenia lub strojów cywilnych z okresu II wojny światowej w wykonaniu grup rekonstrukcyjnych. Członkowie grup nie tylko prezentują swoje kreacje, ale także dokładnie je opisują i odpowiadają na nurtujące uczniów pytania. Projekt kończy się panelem dyskusyjnym, w którym uczestniczą uczniowie oraz zaproszeni goście, wśród nich m.in.: świadkowie historii - uczestnicy powstania warszawskiego, scenarzyści i aktorzy serialu Czas honoru.

Przy pomocy moderatora wydarzenia uczniowie mają możliwość zadawania zaproszonym gościom nurtujących ich pytań o tematyce historycznej. Fundacja Skarby Narodu daje młodym ludziom możliwość skonfrontowania swoich wyobrażeń o II wojnie światowej z prawdziwymi historiami powstańców warszawskich, ale także rozmów z osobami, które kreują wizję II wojny światowej na ekranie. Dzień Patriotyzmu umożliwi nie tylko lepsze zrozumienie historii, ale również spojrzenie na nią z zupełnie innych perspektywy niż dotychczas.

\subsection{Warsztaty „Z historią za pan brat”}

Działalność wystawiennicza Fundacji wciąż się rozwija. Sięgamy po tematy coraz rzadziej poruszane, a nasze ekspozycje są co- 
naszych działań. Pragniemy, aby to młodzież czerpała z tych działań jak najwięcej korzyści, stąd właśnie zrodził się projekt warsztatów „Z historią za pan brat”, dedykowany uczniom szkół średnich i studentom. Ma na celu dogłębne zapoznanie młodzieży z tematami prezentowanych przez Fundację wystaw oraz przygotowanie do dzielenia się tą wiedzą ze zwiedzającymi gośćmi. Szkolenia będą prowadzone przez specjalistów z dziedziny historii, twórców wystaw, a także przez żyjących świadków przedstawianych wydarzeń. Do udziału w warsztatach będą zapraszani uczniowie warszawskich szkół.

\subsection{Piknik historyczny}

Historia przestała być obiektem zainteresowania nie tylko ze strony młodzieży, ale również i osób starszych. W rodzinach zaczynają zanikać przywiązanie do tradycji i patriotyzm. Coraz mniej mówi się o historii swojej ojczyzny, regionu, a także o tradycjach rodzinnych. Rodzice w pędzie życia zapominają przekazać swoim potomkom historie, które sami mogli usłyszeć od swoich przodków.

Piknik historyczny to event skierowany nie tylko do uczniów Gimnazjum nr 38 im. Marii Skłodowskiej-Curie, ale również do ich rodzeństwa, rodziców, dziadków, a także koleżanek i kolegów z innych szkól. Fundacja Skarby Narodu chciałaby wyjść z tym projektem do szerszych kręgów ludzi, zmotywować cale rodziny do poznawania historii, tradycji, kultury swojego kraju.

Podczas eventu odbywa się prezentacja warsztatów „Mój bohater Powstania Warszawskiego". Będzie to niepowtarzalna okazja do przyjrzenia się nieznanym historiom, zobaczenia ich z perspektywy młodych ludzi. Oprócz tego w programie przewidywane są liczne atrakcje, takie jak koncert zespołu, poszukiwanie ukrytych skarbów oraz spotkanie $\mathrm{z}$ grupami rekonstrukcyjnymi.

\subsection{Młodzieżowe Biura Korespondencyjne}

Chcąc poszerzyć swoje działania, Fundacja stworzyła nowy projekt, noszący nazwę Młodzieżowe Biura Korespondencyjne, w którym młodzi ludzie będą wcielali się w rolę historycznych korespondentów z różnych stron Polski. Owoce tej współpracy są publikowane na stronach internetowych Fundacji. Pierwsze takie biuro powstało w Tarnowie w lipcu 2015 roku. 
Podsumowując, Fundacja ma na swoim koncie:

- 20 zrealizowanych projektów

- 2500 uczestników wydarzeń

- 19 wystaw $^{2}$.

ks. Paweł Rycyk CM, Zakony w funkcji krzewienia patriotyzmu, [w:] Życie konsekrowane znakiem wiarygodności Kościola, red. ks. Andrzej Dudek, ks. Robert Kantor, Kraków 2016, s. 245-256 (Lumen Gentium, 2).

DOI: http://dx.doi.org/10.15633/9788374385725.15

2 Fundacja Skarby Narodu, ul. Krakowskie Przedmieście 3, 00-047 Warszawa, mail: biuro@fundacjaskarbynarodu.pl, tel. 882-170-060,www.fundacjaskarbynarodu.pl, https://www.facebook.com/FundacjaSkarbyNarodu. 